\title{
POLA KOMUNIKASI MAHASISWA \\ DALAM PENGGUNAAN SMARTPHONE (Studi pada mahasiswa Marketing Communication FEK Binus University)
}

\author{
Rosidah; Erni Herawati \\ Marketing Communication Department, Faculty of Economic and Communication, BINUS University \\ Jln. K.H. Syahdan No. 9, Palmerah, Jakarta Barat 11480 \\ ochid35@gmail.com; erni_hrwati@yahoo.com
}

\begin{abstract}
This research aimed to identify and know the pattern of smartphone usage among university students and pattern of communication they are doing with the smartphone. Quantitative research was used in this study, with descriptive design. Survey was conducted as data collecting method by distributing questionnaires to students of Marketing Communication (Marcomm) department, Faculty of Economic and Communication (FEK), Binus University. As a result, there were 134 questionnaires that can be proceed for data analysis. Sampling technique used in the research was simple random sampling. Since the research used descriptive design, thus the data analysis technique was descriptive statistics. The research is only limited to study the pattern of smartphone usage and pattern of communication among students of Marcomm department, FEK, Binus University, with their smartphone. Given the fact that smartphone has changed people's behavior in communicating with others, it can be useful for example in developing appealing learning plan in education field, especially for youth. The function of mobile phone has undergone a rapid change with the existence of smartphone. With smartphone, one cannot only perform the traditional types of communication (phone or sms), but also go beyond that. This is due to the features provided by the smartphone which indeed accommodate the person's needs to communicate each other more than just phone calls. Additionally, with the presence of Internet which has made the smartphone becoming inseparable with human's life, since it integrates all medium and activities of communication into a single gadget. Smartphone has been proved to change the people's habit in communicating each other and caused people's dependency on the presence of this medium.
\end{abstract}

Keywords: smartphone, media ecology, pattern of communication, youth

\begin{abstract}
ABSTRAK
Penelitian ini bertujuan untuk mengidentifikasi dan mengetahui pola penggunaan teknologi smartphone di kalangan mahasiswa dan juga pola komunikasi yang mereka lakukan melalui penggunaan smartphone. Metode penelitian kuantitatif digunakan dalam penelitian ini dengan melakukan survei. Kuesioner disebarkan kepada sejumlah mahasiswa jurusan Marketing Communication (Marcomm), Fakultas Ekonomi dan Komunikasi (FEK) Binus University, sehingga didapat 134 kuesioner yang dapat diolah datanya. Simple random sampling diberlakukan dalam prosedur pengambilan responden. Desain penelitian ini adalah deskriptif; dan analisis data juga menggunakan uji statistik deskriptif. Ruang lingkup penelitian ini hanya mempelajari pola penggunaan dan pola komunikasi mahasiswa jurusan Marcomm, FEK Binus University, dalam menggunakan smartphone. Melihat fakta bahwa smartphone mengubah cara seseorang berkomunikasi, maka keadaan dapat dimanfaatkan misalnya dalam dunia pendidikan. Hal ini menjadi tantangan bagi para pendidik untuk menciptakan atmosfer yang menarik bagi generasi muda dalam proses belajar. Fungsi alat komunikasi telepon genggam telah mengalami pergeseran yang pesat dengan adanya smartphone. Seseorang tidak hanya dapat melakukan komunikasi tradisional (telepon atau sms), namun juga melampaui dari itu. Hal ini disebabkan fitur-fitur yang disediakan oleh smartphone memang mengakomodasi kebutuhan seseorang untuk berkomunikasi lebih dari sekadar panggilan telepon. Ditambah lagi dengan adanya Internet, membuat penggunaan smartphone menjadi sesuatu yang tidak bisa lepas dari kehidupan manusia. Smartphone telah terbukti mengubah kebiasaan orang dalam berkomunikasi dan mengakibatkan ketergantungan terhadap keberadaan alat ini.
\end{abstract}

Kata kunci: smartphone, ekologi media, pola komunikasi, generasi muda 


\section{PENDAHULUAN}

Teknologi komunikasi yang berkembang saat ini telah memungkinkan manusia untuk terhubung satu sama lain tanpa dibatasi jarak, ruang, dan waktu. Konvergensi berbagai fungsi dari alat-alat komunikasi telah menyatu dalam sebuah alat komunikasi yang bernama smartphone. Teknologi yang dibawa smartphone membuat penggunanya mempelajari cara-cara baru dalam berkomunikasi. Smartphone menawarkan berbagai aplikasi yang dapat menguatkan komunikasi yang dilakukan oleh manusia. Alat merupakan kepanjangan dari komunikasi yang dilakukan oleh manusia (Loogan, 2010). Penguatan di sini diperlukan karena komunikasi yang dilakukan tidak dalam konteks tatap muka, karenanya baik komunikator maupun komunikan telah kehilangan bahasa nonverbal yang menyertai bahasa verbal dari masing-masing pihak.

Head of VAS, Aplications and Device Management Group Telkomsel, Gideon Edi Purnomo di Jakarta menyebutkan bahwa pertumbuhan pengguna Android di Telkomsel yang mengalami kenaikan hingga 15 kali lipat dalam enam bulan terakhir ini. Ia mengatakan bahwa pada akhir 2011 pengguna Android baru sekitar 170 ribu, sekarang mencapai 2,5 juta atau mengalami kenaikan hingga 15 kali lipat (Republika Online, 2012). Menurut Neraca, pengguna Blackberry Indonesia ternyata merupakan pasar terbesar BlackBerry di Asia Tenggara. Tahun lalu jumlah pelanggan BlackBerry di Indonesia mencapai 2,63 juta dan tahun ini diperkirakan mencapai 4 juta (Harian Neraca, 2011).

Peningkatan secara signifikan jumlah pemakai telepon yang masuk dalam kategori smartphone ini sudah tentu akan menimbulkan suatu fenomena baru bagi pemakainya. Dengan berbagai perangkat yang dirawarkan tersebut, maka manusia kemudian memahami bahwa dunia yang mereka bangun tidak lagi sama dengan sebelumnya. Melalui alat komunikasi dengan teknologi terbaru, mereka telah berubah dan mempraktikkan cara-cara komunikasi yang baru. Hal ini sejalan dengan apa yang dikatakan oleh Marshall McLuhan bahwa manusia membentuk alat-alat komunikasi, tetapi pada akhirnya alat-alat tersebut akan membentuk manusia (Hafner \& Jones, 2012). Media memiliki kekuatan untuk memengaruhi makna yang dibuat oleh seseorang, hubungan dirinya dengan orang lain, akan menjadi manusia seperti apa orang tersebut, dan hal-hal yang akan dipikirkan olehnya. Demikian, pada akhirnya pola-pola baru dalam berkomunikasi ini akan membentuk sebuah kebiasaan dan budaya baru.

Hubungan timbal balik antara keberadaan teknologi dengan perilaku manusia dapat juga digambarkan melalui riset yang menjelaskan bahwa ada perbedaan yang signifikan dalam perilaku manusia ketika mereka dihadapkan pada alat (device) yang berbeda (Oulasvirta, Rattenbury, Ma, \& Raita, 2012). Perilaku pengguna smartphone menunjukkan bahwa perilaku checking dilakukan dua kali lipat lebih banyak dibanding laptop, dan durasi yang dihabiskan untuk mengecek smartphone lebih sebentar dibanding dengan laptop. Namun demikian, keberadaan alat komunikasi tersebut mempunyai kecenderungan yang sama bagi penggunanya yaitu timbulnya kebiasaan untuk mengecek, meskipun dengan intensitas yang berbeda-beda. Setiap nilai informasi yang didapat dari smartphone membuat intensitas untuk mengecek juga meningkat.

Dari fakta mengenai perkembangan jumlah pemakaian smartphone di Indonesia dan hasil studi yang disampaikan tersebut, maka terdapat beberapa permasalahan yang cukup penting untuk diangkat dalam penelitian ini, antara lain: (1) Bagaimana pola penggunaan teknologi smartphone oleh mahasiswa jurusan marketing communication, FEK, Binus University? (2) Bagaimana pola komunikasi mahasiswa jurusan marketing communication, FEK, Binus University yang dilakukan melalui penggunaan smartphone?

Penelitian ini membatasi ruang lingkup yaitu hanya mempelajari perilaku komunikasi pada mahasiswa jurusan Marketing Communication (Marcomm), Fakultas Ekonomi dan Komunikasi 
(FEK), Binus University. Hal ini dilakukan karena sejalan dengan tujuan belajar mengajar pada jurusannya, mahasiswa Marcomm dituntut untuk memiliki kemampuan berkomunikasi yang baik. Salah satu caranya adalah dengan menggunakan teknologi yang berkembang sekarang ini, seperti smartphone. Peneliti menyadari bahwa penelitian ini merupakan sebuah studi pendahuluan, yang nantinya dapat dilakukan pada ruang lingkup yang lebih luas lagi, untuk membuktikan bahwa karakter samel ini sama atau berlaku untuk populasi yang lebih luas. Demikian pula penelitian selanjutnya dapat meneliti variabel lain yang berkaitan dan metodologi yang dapat menunjukkan hubungan dan/atau pengaruh dari teknologi smartphone terhadap sikap atau perilaku komunikasi mahasiswa.

Penelitian ini bertujuan secara khusus untuk menjelaskan hal-hal seperti berikut. Pertama, penelitian bertujuan untuk mengidentifikasi dan mengetahui deskripsi pola penggunaan teknologi smartphone oleh mahasiswa Marcomm, FEK, Binus University. Kedua, penelitian bertujuan untuk mengidentifikasi dan mengetahui deskripsi pola komunikasi mahasiswa Marcomm, FEK, Binus University melalui penggunaan smartphone. Ketiga, penelitian bertujuan untuk mempelajari seberapa jauh daya tarik smartphone menurut mahasiswa dan seberapa jauh sikap mereka dalam berkomunikasi dengan menggunakan smartphone.

Secara umum hasil penelitian ini dapat dimanfaatkan untuk mendapatkan deskripsi pola penggunaan teknologi smartphone dan pola komunikasi oleh mahasiswa melalui penggunaan teknologi samrtphone. Secara khusus penelitian dapat dimanfaatkan oleh Binus University ataupun institusi pendidikan lainnya untuk memaksimalkan fungsi smartphone kepentingan belajar mengajar.

\section{Tinjauan Pustaka}

Latar belakang pemikiran ekologi media adalah tentang perkembangan teknologi memengaruhi kehidupan manusia dan membentuk cara hidup manusia. Terdapat tiga asumsi yang menjadi titik penting dalam teori ekologi media, yaitu: 1) media melingkupi setiap tindakan dalam masyarakat; 2) media memperbaiki persepsi manusia dan mengorganisasikan pengalamannya; 3) media menyatukan seluruh dunia (West \& Turner, 2008, hal. 140). Berdasarkan yang dikatakan oleh Mc Luhan bahwa media telah melingkupi setiap dimensi kehidupan manusia sehingga secara tidak langsung mereka dipengaruhi oleh media. Pada akhirnya media membuat kehidupan manusia layaknya sebuah desa global (global village) yang telah diikat menjadi sebuah sistem politik, ekonomi, sosial, dan budaya.

Terjadinya desa global tersebut menurut Mc Luhan disebabkan oleh adanya media elektronik. Dengan media elektronik maka manusia tidak dapat lagi hidup dalam isolasi karena adanya saling ketergantungan elektronik (West \& Turner, 2008, hal. 141). Dalam hukum media (Laws of media) disebutkan bahwa teknologi memengaruhi komunikasi melalui teknologi baru. Perubahan masyarakat yang dipengaruhi teknologi akan lebih jauh pula memengaruhi teknologi berikutnya. Dalam hukum media ini terdapat empat hal yang ditanyakan, yaitu: 1) apakah yang ditingkatkan oleh media; 2) apakah yang dibuat ketinggalan zaman oleh media; 3) apakah yang diambil kembali oleh media; 4) apakah yang diputarbalikkan oleh media (West \& Turner, 2008, hal. 149).

Seperti juga televisi yang telah menjadi medium pribadi dalam hal pemutaran video, demikian juga Internet yang telah meningkatkan komunikasi masyarakat dengan cara yang berbeda dan juga telah memutarbalikkan masyarakat menjadi tempat yang baru dan unik, yang kemudian membawa kembali masyarakat ke era tribal untuk berkomunikasi antarpribadi satu dengan yang lain dalam chat room. Internet punya kemampuan untuk mengunduh musik, acara televisi, dan film pendek.

Kemunculan Internet telah mengubah dunia seseorang dan membuatnya memperbaharui cara mereka dalam berkomunikasi. Hal ini sesuai dengan yang disampaikan oleh Marshall McLuhan, yaitu: "We shape our tools and thereafter our tools shape us" (Loogan 2010). Medium yang digunakan oleh 
komunikator untuk menyampaikan pesan menjadi bagian yang tidak kalah penting adalah tentang pesan dapat disandi dan diterima oleh komunikan. Manusia telah menciptakan alat-alat teknologi komunikasi untuk mengatasi hambatan-hambatan dalam berkomunikasi, tetapi alat-alat tersebut pada akhirnya membentuk dunia seseorang menjadi berbeda dari yang sebelumnya. Alat-alat komunikasi yang diciptakan manusia pada akhirnya menjadi kepanjangan dari diri mereka untuk berkomunikasi, tetapi ironisnya justru manusia akan menjadi kepanjangan tangan dari alat-alat komunikasi tersebut. Saat ini manusia telah mengubah alat komunikasi dari yang sebelumnya adalah televisi menjadi alat komunikasi berbasis online.

Dalam ekologi media, konsep "the medium is the message" mengandung arti bahwa era elektronik secara total telah menciptakan lingkungan baru. Lingkungan yang baru ini telah memproses kembali lingkungan yang lama seperti televisi telah memproses kembali film-film. Postman menyebutkan bahwa ekologi media sebenarnya adalah studi tentang media sebagai lingkungan. Maksudnya adalah tentang cara media komunikasi dapat memengaruhi persepsi, pemahaman, perasaan, dan nilai manusia. Selanjutnya, cara manusia berinteraksi dengan media akan memberikan kesempatan kepada mereka untuk bertahan hidup (Strate, 2004, hal. 4). Ekologi dapat dimaksudkan sebagai lingkungan (struktur, isi, dan dampaknya pada masyarakat). Lingkungan ini berisi teknikteknik seperti teknologi, simbol-simbol seperti alat, sistem informasi seperti mesin (Strate, 2004). Selanjutnya, Postman menggambarkan bahwa ekologi media sebagai studi tentang transaksi antarmanusia, pesan-pesan mereka, dan sistem-sistem dalam pesan mereka.

Postman dkk. juga menyatakan bahwa sebuah medium adalah sebuah teknologi yang di dalamnya tumbuh sebuah budaya (Valcanis, 2011). Ditambahkan juga, bahwa Postman memberikan pertanyaan-pertanyaan berkaitan dengan penggunaan facebook, blog, dsb. Kemunculan teknologi telah memungkinkan manusia mempunyai budaya yang sebelumnya tidak ada menjadi ada. Postman juga mencatat bahwa teknologi media baru tidak sekadar menambahkannya pada budaya, tetapi mentransformasikan budaya. Ekologi media telah dipakai oleh Valcanis sebagai analisis untuk melihat jika globalisasi dan teknologi dalam era informasi yang telah dibawa oleh konvergensi media (ICT dan komputer, Internet, social media, termasuk smartphone) yang saat ini dialami oleh manusia merupakan sebuah transformasi dan fenomena budaya yang total (Valcanis, 2011). Hasilnya mengatakan bahwa budaya telah secara radikal tertransformasi. Padahal untuk bisa terhubung dengan Internet setiap orang harus membeli komputer atau smartphone dan tentunya terhubung dengan Internet.

Smartphone pada dasarnya adalah sebuah istilah yang dipakai untuk menunjukkan teknologi telepon dengan fungsi yang telah meluas. Secara harfiah berarti telepon pintar, yaitu telepon seluler yang mempunyai kemampuan seperti Personal Computer dengan kemampuan untuk menambah aplikasi-aplikasi baru. Fitur-fitur yang terdapat di dalamnya antara lain: adanya sistem operasi, kemampuan untuk terhubung ke Internet, mampu untuk ditambah piranti lunak, dilengkapi kamera, dan mampu membaca dokumen-dokumen bisnis (Zaki, 2008). Teknologi ini tidak hanya mampu membuat dan mengirimkan suara, tetapi juga suara dan gambar bahkan moving image.

Smartphone merupakan sebuah perangkat yang memungkinkan untuk melakukan komunikasi seperti menelepon atau berkirim pesan singkat, yang juga di dalamnya terdapat fungsi PDA (Personal Digital Assistant) dan berkemampuan seperti layaknya komputer (Harian Neraca, 2011). Dalam sebuah smartphone, terdapat komponen-komponen yang mendukung cara kerja dari smartphone tersebut, antara lain sistem operasi yang memungkinkan manusia menjalankan berbagai ditujukan untuk meningkatkan produktivitas dan mendukung kegiatan sehari-hari, misalnya aplikasi Doc To Go untuk membuat dan aplikasi. Smartphone selalu dilengkapi berbagai aplikasi atau software yang tentunya mengedit dokumen Word di Smartphone. Kemampuan lain yang dimiliki smartphone adalah bisa digunakan untuk mengakses Internet dengan konten yang disajikan di browser-nya sudah hampir mendekati layaknya seseorang mengakses web lewat komputer seperti Opera Mobile (Harian Neraca, 2011). 
Istilah Internet tidak hanya sebatas pada pengertian teknologi yang menghubungkan antarkomputer semata, tetapi sering kali mengandung fenomena sosial sebagaimana yang terjadi dalam interaksi antarindividu secara face to face (Nasrullah, 2012). Kata Internet bisa didenotasikan sebagai seperangkat program komputer yang memungkinkan user untuk melakukan interaksi, memunculkan berbagai macam bentuk komunikasi, serta untuk bertukar informasi (Nasrullah, 2012). Perkembangan program seperti email, IRC, bulletin boards, MUDs, video konferensi, dan kemunculan www atau world wide web pada dasarnya adalah pembuktian bahwa teknologi baru semakin berkembang (Nasrullah, 2012).

Smartphone sudah seperti personal computer namun dapat digenggam, yang merepresentasikan langkah terbaru dalam evolusi informasi portabel dan teknologi komunikasi. Smartphone, yang dilengkapi dengan konektivitas jaringan yang persisten dan mendukung instalasi aplikasi-aplikasi baru, memiliki potensi untuk menghasilkan kebiasaan baru yang terkait dengan penggunaan Internet (Oulasvirta, Rattenbury, Ma, \& Raita, 2012).

Di Indonesia pertumbuhan penggunaan smartphone (ponsel pintar) cukup signifikan. Ditambah lagi dengan dukungan dari layanan seluler prabayar yang ada di negara ini. Sistem operasi BlackBerry mendominasi pasar smartphone di Indonesia dengan 27\%, diikuti oleh Symbian 20\%, dan Android 10\%. Posisi keempat dan kelima diduduki oleh Windows Phone sebesar 8\% dan iOS 2\% (Panji, 2012).

Tidak dipungkiri lagi bahwa mobile phone telah mengubah cara komunikasi antarmanusia, terutama kaum muda. Terlebih lagi, dengan kehadiran smartphone yang mengintegrasikan semua media dan aktivitas komunikasi dalam satu gadget, telah membuat kaum muda semakin terhanyut dengan penggunaan teknologi mobile, dibanding generasi sebelumnya (AC Nielsen, 2010).

Smartphone telah berhasil mencuri hati generasi muda. Dengan banyaknya manfaat yang didapat dari penggunaan smartphone, misalnya untuk mengunduh banyak aplikasi, seperti kamus, peta, games, dan lain-lain. Smartphone juga memungkinkan mereka untuk selalu terhubung 24 jam sehari, 7 hari seminggu, dengan Internet. Ditambah lagi dengan meningkatnya penggunaan jejaring sosial, seperti facebook dan twitter, membuat kaum muda semakin ingin selalu terhubung dengan Internet (deccanherald.com, nd).

Selain itu, penelitian di Amerika Serikat menunjukkan bahwa kaum muda merupakan golongan yang paling sering melakukan komunikasi dengan berbagai pihak, seperti teman, guru, orangtua, dan sebagainya. Dengan memiliki smartphone, maka kebutuhan tersebut semakin tersalurkan dengan baik (Lenhart, 2012 ).

\section{METODE PENELITIAN}

Penelitian ini menggunakan pendekatan kuantitatif. Menurut Kriyantono (2006), penelitian kuantitatif adalah penelitian yang menggambarkan atau menjelaskan suatu masalah yang hasilnya dapat digeneralisasikan. Penelitian kuantitatif tidak terlalu mementingkan kedalaman data atau analisis. Peneliti lebih mementingkan aspek keluasan data sehingga data atau hasil riset dianggap merupakan representasi dari seluruh populasi.

Metode penelitian yang dilakukan dalam penelitian ini adalah survei. Metode ini menggunakan kuesioner sebagai instrumen pengumpulan datanya (Kriyantono, 2006). Lebih lanjut Kriyantono menjelaskan bahwa tujuan dari metode survei adalah untuk memperoleh informasi tentang sejumlah responden yang dianggap mewakili populasi tertentu. Secara khusus, jenis desain yang 
digunakan adalah penelitian deskriptif. Jenis ini digunakan untuk menggambarkan (mendeskripsikan) populasi yang sedang diteliti (Kriyantono, 2006). Sejalan dengan desain ini, analisis data yang digunakan adalah uji statistik deskriptif, yaitu frequency distribution.

Kuesioner didesain dalam beberapa bagian sesuai dengan tujuan penelitian, yaitu bagian untuk menanyakan karakteristik umum responden, bagian untuk menanyakan pola penggunaan smartphone secara umum, dan bagian untuk mengetahui pola komunikasi responden melalui penggunaan smartphone. Pertanyaan-pertanyaan yang diajukan juga didesain untuk single response dan multiple responses, untuk mengakomodasi jawaban dari responden.

Teknik sampling yang digunakan adalah sampling random sederhana (simple random sampling). Teknik sampling probabilitas ini memberikan peluang kepada seluruh anggota populasi untuk dipilih menjadi sampel (Kriyantono, 2006). Peneliti menyebarkan kuesioner ke kelas-kelas jurusan Marcomm yang dipilih secara acak, dan memberikan kuesioner kepada mereka yang sedang berada di kelas. Populasi mahasiswa Marcomm Binus aktif periode 2009-2012 berdasarkan catatan LIM Binus University tahun 2013 berjumlah 1,851 orang (wawancara peneliti). Rumus Slovin digunakan untuk menentukan jumlah sampel karena jumlah populasi diketahui dengan pasti. Dengan derajat signifikansi 10\% (kelonggaran ketidaktelitian), maka jumlah sampel minimal adalah 94,9, dibulatkan menjadi 95 mahasiswa. Dalam penelitian ini responden yang didapat adalah 196 mahasiswa. Namun setelah dilakukan editing dan data cleaning, hanya 134 kuesioner yang dapat digunakan untuk proses analisis selanjutnya.

\section{HASIL DAN PEMBAHASAN}

\section{Karakteristik Responden}

Penelitian melibatkan 134 responden dari mahasiswa jurusan Marketing Communication (Marcomm), Fakultas Ekonomi dan Komunikasi (FEK), Binus University. Responden yang paling banyak adalah perempuan yaitu sebanyak $70.1 \%$ dan laki-laki sebanyak $28.4 \%$, namun di antara responden terdapat $1.5 \%$ yang tidak menjawab pertanyaan tentang jenis kelamin. Usia terbanyak responden adalah antara 20 sampai dengan 23 tahun yaitu sebanyak 56.6\%, sedangkan usia di bawah 20 tahun sebanyak $40.2 \%$. Di antara mahasiswa yang menjadi responden, terdapat juga mereka yang berusia di atas 23 tahun yaitu sebanyak 3\%.

Untuk mengetahui persentase biaya yang dikeluarkan untuk keperluan komunikasi, maka sebelumnya responden ditanya tentang jumlah pengeluaran mereka dalam sebulan. Dari semua responden rata-rata pengeluaran terbanyak adalah lima ratus ribu rupiah sampai dengan satu juta rupiah yaitu sebanyak 42.5\%. Posisi terbanyak setelahnya adalah pengeluaran antara satu juta sampai dengan dua juta rupiah (33.6\%), sedangkan pengeluaran di bawah lima ratus ribu rupiah hanya sebanyak $6 \%$. Namun demikian masih terdapat $2.2 \%$ responden yang tidak bersedia menjawab jumlah pengeluaran mereka dalam sebulan.

Secara singkat data tentang karakteristik responden dapat dibaca dalam tabel berikut.

Tabel 1 Karakteristik Responden

\begin{tabular}{ccccccccccc}
\hline \multicolumn{3}{c}{ Jenis kelamin } & \multicolumn{3}{c}{ Usia } & \multicolumn{5}{c}{ Total pengeluaran perbulan } \\
\hline Lk & $\operatorname{Pr}$ & No & $<20$ th & $20-23$ & $>23$ th & $<500$ rb & 500rb sd 1juta & $>1$ juta sd 2juta & $>2$ juta & No \\
\hline$(\%)$ & $(\%)$ & $(\%)$ & $(\%)$ & $(\%)$ & $(\%)$ & $(\%)$ & $(\%)$ & $(\%)$ & $(\%)$ & $(\%)$ \\
28.4 & $\mathbf{7 0 . 1}$ & 1.5 & 40.2 & $\mathbf{5 6 . 6}$ & 3.0 & 6.0 & $\mathbf{4 2 . 5}$ & 33.6 & 15.7 & 2.2 \\
\hline \multicolumn{3}{c}{100.00} & \multicolumn{10}{c}{100.00} & & & & 100.00 & & \\
\hline
\end{tabular}

Sumber: Data Penelitian 


\section{Pola Penggunaan Teknologi dalam Smartphone}

Data mengenai pola penggunaan smartphone akan menggambarkan penggunaan teknologi smartphone oleh responden. Secara umum data yang diambil meliputi lama mereka telah memakai smartphone, biaya yang dihabiskan, serta kaitannya dengan penggunaan aplikasi edukasi dalam smartphone yang mereka miliki. Peneliti tertarik untuk melihat aplikasi edukasi karena salah satu tujuan dari hasil ini adalah untuk melihat kemungkinan memaksimalkan penggunaan smartphone untuk menunjang proses belajar mengajar.

Hasil jawaban menunjukkan bahwa dari seluruh responden selain menggunakan smartphone, sebagian dari mereka juga menggunakan alat komunikasi lain yaitu telepon genggam jenis CDMA dan/atau GSM. Pertanyaan ini menggunakan multiple response. Jika diakumulasikan, hasil sebarannya yaitu: sebanyak 69.4 \% menggunakan Smartphone, 23.8 \% menggunakan telepon jenis GSM, dan sebanyak 6.7\% mengggunakan telepon jenis CDMA. Di antara mereka, 70.1\% mengaku terus terhubung dengan Internet, sejumlah $26.9 \%$ di antaranya hanya kadang-kadang. Akan tetapi, terdapat $3 \%$ dari mereka yang mengaku tidak terhubung dengan Internet. Mereka yang mengunduh aplikasi lewat smartphone lebih dari empat kali seminggu sejumlah 35.1\% dan yang kurang dari itu sebanyak 48.5\%. Sedangkan sisanya sebanyak $16.4 \%$ tidak pernah mengunduh aplikasi melalui smartphone. Aplikasi yang dimaksud di sini adalah aplikasi secara umum, yang termasuk di dalamnya seperti musik, games, education, dan lain-lain.

Untuk pemilikan dan lamanya penggunaan smartphone, sebagian besar dari responden yaitu sejumlah 56\% telah menggunakan smartphone lebih dari dua tahun. Sedangkan responden yang baru menggunakan smartphone antara 1-2 tahun sebanyak 35.1\%. Sejumlah 38.1\% di antara mereka bahkan memiliki smartphone lebih dari satu. Jenis smartphone yang dimiliki oleh responden kebanyakan berjenis BlackBerry sebanyak 65.3\%, disusul oleh Android sebanyak 23.9\%. Hal ini sesuai dengan yang diutarakan sebelumnya, bahwa Indonesia merupakan negara dengan pengguna BlackBerry terbanyak, yang sudah mencapai empat juta orang (Harian Neraca, 2011). Kompas.com menambahkan, setidaknya sampai Agustus 2012 Indonesia adalah negara dengan pengguna BlackBerry terbesar di kawasan Asia Pasifik (Panji, 2012).

Untuk kepentingan penggunaan aplikasi-aplikasi yang tersedia dalam smartphone, maka keleluasaan penggunaan tergantung pada besaran biaya yang dikeluarkan untuk membeli jasa pelayanan yang disediakan oleh jasa penyedia layanan. Jawaban responden menunjukkan bahwa sebagian besar dari mereka mengeluarkan biaya antara lima puluh rupiah sampai dengan seratus ribu rupiah yaitu sebesar $47.8 \%$. Untuk besaran antara seratus ribu rupiah sampai dengan seratus lima puluh ribu rupiah sebanyak $18.7 \%$. Mereka yang mengeluarkan biaya di bawah lima puluh ribu rupiah masih cukup banyak yaitu sebesar $11.2 \%$, dan yang menghabiskan biaya di atas seratus lima puluh ribu rupiah juga cukup besar yaitu sejumlah $22.4 \%$.

Dalam hal pemanfaatan smartphone untuk kepentingan edukasi, maka jawaban yang paling banyak dipilih responden adalah pemanfaatan smartphone untuk mengunduh aplikasi kamus bahasa asing (32.4\%) dan layanan terjemahan (24.3\%). Beberapa di antara mereka juga memanfaatkan smartphone mereka untuk mengunduh materi-materi kuliah dari Binusmaya yaitu sejumlah 23.5\%. Untuk diketahui, pertanyaan ini menggunakan multiple responses.

\section{Pola Komunikasi melalui Smartphone}

Pola komunikasi responden melalui pengggunaan smartphone salah satunya dapat dilihat dari responden yang terhubung dengan kelompok sosial dan yang bergabung di dalamnya. Persentase yang paling besar tentang jumlah kelompok sosial yang responden terhubung melalui smartphone-nya yaitu sejumlah tiga sampai dengan lima kelompok sosial yang dimiliki oleh responden sebesar 37.3\%. Jumlah terbesar kedua yaitu responden yang tergabung dalam lima sampai sepuluh kelompok yaitu 
sebesar 24.6\%. Ada pula responden dalam smartphone mereka sampai memiliki jumlah kelompok sosial sampai dengan lebih dari sepuluh kelompok yaitu sebesar 17.2\%. Sedangkan responden yang hanya tergabung kurang dari tiga kelompok sosial yaitu sebesar $19.4 \%$.

Di antara beberapa kategori kelompok sosial yang terhubung dengan mereka melalui smartphone, diketahui bahwa jumlah kelompok sosial yang paling banyak terhubung dengan responden adalah komunikasi dengan teman sekelas (26.6\%). Jumlah yang hampir sama muncul pada komunikasi dengan teman-teman dekat atau sahabat (25.9\%). Kelompok sosial untuk keluarga menempati urutan ketiga yaitu sejumlah 18.5\%. Meskipun sedikit, beberapa dari mereka juga menggunakan smartphone untuk terhubung dengan kelompok belanja online (2.6\%). Namun dari data yang dikumpulkan, ternyata keterhubungan komunikasi para responden dalam kelompok social chatting, motivasi terbesar lebih banyak dilatarbelakangi oleh kepentingan untuk iseng dan mengobrol tanpa arah maupun gosip (31.2\%). Selanjutnya mereka akan terhubung dengan social chatting untuk mendiskusikan masalah perkuliahan (26\%). Selain kedua hal tersebut, komunikasi dengan menggunakan social chatting juga untuk kepentingan mendiskusikan pekerjaan (11.1\%) dan untuk berkenalan (12.6\%). Kedua pertanyaan ini menggunakan metode multiple responses.

Dalam berkomunikasi tersebut, smartphone juga menyediakan beberapa fasilitas untuk memperlancar komunikasi yang bukan tatap muka, yaitu dengan memberikan penguatan terhadap pesan yang dikirim melalui perantaraan simbol dan fasilitas lainnya. Sebesar $45 \%$ menjawab mereka menggunakan fasilitas emoticon, selanjutnya mereka menggunakan foto dalam mendukung komunikasi yaitu dijawab oleh sebesar $29.7 \%$ dan sejumlah $18 \%$ menyatakan bahwa mereka lebih memilih menggunakan suara. Sebesar $2.7 \%$ menggunakan video. Namun, $4.5 \%$ menjawab tidak menggunakan semua fasilitas pendukung tersebut dalam berkomunikasi.

Tergabungnya mereka dalam kelompok sosial tentunya akan membuat mereka menjadi sering berkomunikasi di dalamnya. Oleh karena itu, perlu diketahui seberapa penting bagi responden untuk menjawab sesegera mungkin pesan yang masuk dalam smartphone mereka. Terhadap pertanyaan tersebut, maka sebagian besar responden yaitu $73.9 \%$ menyatakan penting untuk segera menjawab, dan selebihnya mengatakan tidak penting untuk segera menjawabnya, yaitu sebesar $24.6 \%$. Hal ini tentu akhirnya akan berkaitan dengan seberapa sering mereka membuka dan mengecek smartphone mereka. Dalam hal ini peneliti memberi batasan waktu dalam satu jam. Sebesar 38.8\% menyatakan mereka membuka atau mengecek smartphone mereka sebanyak lima sampai sepuluh kali dalam satu jam. Angka yang cukup tinggi juga didapat dari mereka yaitu sebesar $32.1 \%$ yang menyatakan bahwa mereka membuka dan mengecek smartphone mereka sebanyak lebih dari sepuluh kali dalam satu jam. Frekuensi terkecil ada pada responden yang menjawab kurang dari lima kali membuka dan mengecek smartphone-nya dalam satu jam yatu sebesar $12.7 \%$. Sisanya sebesar $16.4 \%$ menjawab membuka smartphone mereka antara sepuluh sampai lima belas kali dalam satu jam.

Berkaitan dengan jawaban tersebut, maka dari jawaban responden terbesar yaitu 23.2\% menyebutkan bahwa meraka akan melihat dan/atau membuka smartphone mereka ketika mereka sedang menunggu. Sebesar 16.6\% menyebutkan bahwa mereka melihat smartphone ketika mereka baru bangun tidur dan sebesar $14.3 \%$ ketika akan tidur. Di antara mereka juga mengakui bahwa mereka juga membuka dan melihat smartphone mereka ketika sedang di dalam kelas atau kuliah sedang berlangsung, yaitu sebesar $11.9 \%$. Bahkan $8.6 \%$ responden melihat dan membuka smartphone ketika mereka ada di dalam toilet.

Frekuensi mereka untuk melihat dan/atau membuka smartphone tersebut akan memperlihatkan sejauh mana responden akan terus berdekatan dengan alat komunikasi tersebut. Sehingga ketika ditanyakan jauh/tidaknya mereka dari smartphone mereka ketika mereka tidur, sebesar 52.2\% responden menjawab jarak mereka dari smartphone mereka tidak sampai satu meter. Selanjutnya sebesar 31.3\% menjawab bahwa jarak mereka dari smartphone sejauh satu sampai dengan dua meter. Responden yang menjawab jarak mereka dengan smartphone mereka sejauh dua sampai tiga meter 
sebesar $11.9 \%$. Sisanya menjawab bahwa jarak mereka dengan smartphone lebih dari tiga meter (4.5\%).

Berkaitan dengan banyaknya aplikasi yang ditawarkan oleh smartphone, diketahui bahwa kegunaan smartphone untuk melakukan sambungan telepon masih menempati posisi yang cukup tinggi (12\%), tetapi jumlah penggunaan untuk mengirim pesan dalam bentuk teks (pesan tertulis di sini termasuk diantaranya menggunakan fasilitas keterhubungan dengan social chatting) masih sedikit lebih tinggi yaitu sejumlah 12.2\%. Fungsi lain dari smartphone yang banyak dipakai oleh responden yaitu untuk browsing atau mencari informasi sebesar $11.7 \%$. Jumlah yang hampir sama muncul untuk penggunaan smartphone sebagai media sosial yaitu sebesar $11.8 \%$. Fungsi lain yang juga cukup tinggi jumlah responden yang menjawab adalah untuk mendengarkan musik, yang dijawab oleh 10.8\% responden dan kegunaannya untuk memotret dan membuat video yaitu sebesar 9.6\%.

Sehubungan dengan pertanyaan di atas, jika responden dipaksa untuk memilih tiga penggunaan smartphone yang paling sering dilakukan (untuk mengukur prioritas penggunaan), mereka memberi jawaban sebagai berikut: tiga kegiatan paling sering dilakukan dengan menggunakan smartphone adalah melakukan text message (41.8\%), diikuti oleh kegiatan di social media (31.3\%), dan fungsi tradisional, yaitu menelepon (10.4\%). Sementara kegiatan lain masih dipilih, walaupun dalam tingkat yang lebih rendah, seperti browsing (untuk mencari informasi), mendengarkan musik, membuat foto/video, dan sebagainya. Namun yang menarik adalah tidak ada yang membuat prioritas pada penggunaan smartphone untuk panduan berkendara (GPS) dan sebagai sarana e-learning (membaca, mengunggah dan mengunduh materi kuliah).

Meskipun smartphone telah menyediakan fasilitas yang memberikan kemudahan untuk orang lain saling terhubung dan berkomunikasi, sebanyak 80.6\% menyatakan kadang-kadang mereka mengalami kesalahpahaman dalam berkomunikasi. Sedikit dari responden yaitu sebesar 9.7\% menyatakan sering mengalami kesalahpahaman. Angka yang sama juga dijawab oleh responden yang tidak pernah mengalami kesalahpahaman dalam berkomunikasi dengan smartphone.

\section{Lain-lain}

Kebiasaan berkomunikasi dengan menggunakan media smartphone tentunya akan membawa implikasi bagi penggunanya ketika mereka pada suatu saat tidak membawa smartphone. Dalam studi ini, peneliti juga tertarik untuk mengetahui perasaan responden bila tidak membawa smartphone dalam satu hari. Bila responden sudah merasa terbiasa 'hidup' dengan smartphone mereka, tentunya akan menimbulkan situasi yang tidak biasa (aneh) ketika satu hari tidak bersama smartphone. Hasil yang didapat adalah sebagai berikut: jawaban yang paling banyak didapat dari pertanyaan yang peneliti ajukan adalah para responden merasa hidupnya tidak lengkap (merasa kehilangan sesuatu yang berharga) sebanyak $24.6 \%$. Kemudian disusul dengan perasaan bosan, tidak tahu harus berbuat apa (lebih spesifik, responden menjawab bete atau mati gaya) sebanyak 23.1\%. Responden juga merasa tidak tenang, karena susah untuk berkomunikasi tanpa smartphone mereka (22.4\%). Namun, ada juga responden yang merasa biasa saja, dan harus dapat menyesuaikan diri dengan keadaan tersebut (18.7\%), dan sisanya tidak menjawab.

Berbagai macam teknologi yang ada saat ini dapat dipakai sebagai sarana untuk berkomunikasi. Oleh karenanya perlu untuk ditanyakan alasan-alasan mendasar responden yang diteliti memutuskan untuk memilih menggunakan smartphone. Kategori jawaban yang paling tinggi adalah karena mereka memang membutuhkan smartphone sebagai alat untuk berkomunikasi (31.3\%). Lebih lanjut ada responden yang memilih smartphone dari segi kepraktisan karena teknologi smartphone yang multifungsi (19.4\%) dan menyediakan semua kebutuhan komunikasi. Ada juga responden yang memilih smartphone karena mengikuti tren atau perkembangan zaman. Mereka menganggap sebagai bagian gaya hidup sehingga harus mengikuti tren/perkembangan ini sebagai gaya hidup (19.4\%). Sebagian kecil (4.5\%) menyatakan bahwa mereka memilih menggunakan smartphone 
karena terpaksa. Hal ini disebabkan orang-orang atau teman-teman mereka banyak yang menggunakan smartphone (lebih spesifiknya lagi, responden menjawab BlackBerry). Sehingga jika mereka ingin tetap update dengan berita terkini dan terhubung dengan teman-teman, mereka harus memilih smartphone tersebut.

\section{SIMPULAN}

Fungsi alat komunikasi panggilan telepon telah mengalami pergeseran yang pesat dengan adanya smartphone. Smartphone sudah seperti sebuah personal computer yang dapat digenggam, dapat dibawa ke mana-mana (portable), dan mengintegrasikan semua kebutuhan komunikasi manusia. Penggunaan teknologi ini membuat individu dapat terhubung dengan individu yang lain melalui pengalaman yang baru. Ditambah lagi dengan adanya jaringan Internet, membuat pembentukan suatu kebiasaan baru pada manusia untuk selalu menggenggam smartphone di mana saja mereka berada.

Dalam penelitian ini, sesuai dengan fakta yang disebutkan, Indonesia adalah negara dengan pengguna BlackBerry terbesar, setidaknya di Asia Pasifik, maka responden penelitian ini pun kebanyakan menggunakan BlackBerry (65.3\%). Dari sebagian pengguna BlackBerry, ada yang menyadari pentingnya penggunaan smartphone ini untuk kemudahan berkomunikasi. Namun ada juga yang merasa terpaksa memilikinya karena orang-orang sekelilingnya menggunakan smartphone jenis ini (4.5\%). Sehingga agar tetap terhubung dengan mereka dan tidak ketinggalan berita, mereka beralih menggunakan BlackBerry. Lebih dari 70 \% responden mengaku selalu terhubung dengan Internet. Rata-rata terbesar pengeluaran untuk biaya komunikasi smartphone oleh mahasiswa antara lima puluh ribu sampai dengan seratus ribu rupiah. Pemakaian terbesar aplikasi yang ada hubungannya dengan pendidikan adalah untuk membuka kamus atau layanan terjemahan.

Prioritas mengenai penggunaan smartphone lebih besar untuk melakukan text message (41.8\%), diikuti oleh kegiatan di social media (31.3\%) dan menelepon (10.4\%). Menarik untuk diketahui, kegiatan-kegiatan lain seperti browsing, mendengarkan musik, membuat foto/video, dan lain-lain, meskipun masih rendah masih ada yang memilih sebagai prioritas ke sekian. Namun tidak ada responden yang memilih e-learning sebagai prioritas. Suatu tantangan bagi para pendidik, utamanya, untuk menciptakan program atau aktivitas yang mendorong proses belajar mengajar melalui smartphone, mengingat si terdidik sudah familiar dan dekat dengan alat tersebut.

Smartphone pun membentuk pola komunikasi yang khas, yang dilakukan oleh kaum muda, dalam hal ini mahasiswa. Hal ini dapat dilihat dari jarak antara responden dengan smartphone, bila mereka rehat atau tidur, adalah kurang dari satu meter (52.2\%). Hal ini menunjukkan tingkat kepentingan smartphone dalam hidup mereka, sehingga tidak dapat terlalu jauh untuk dapat menjangkau gadget tersebut. Hal ini disebabkan, bagi sebagian responden, sangat penting untuk menjawab pesan di Smartphone sesegera mungkin (73.9\%).

Pola komunikasi dengan menggunakan smartphone memperlihatkan bahwa rata-rata responden terhubungan dengan tiga sampai lima kelompok sosial, paling banyak adalah dengan teman sekelas mereka. Motivasi terbesar untuk mengobrol dalam kelompok sosial adalah sekedar untuk iseng atau obrolan ringan saja. Kebiasaan mengecek alat mereka terbesar adalah lima sampai sepuluh kali dalam satu jam. Intensitas mengecek smartphone dapat dilihat dari tingkat persentase yang rata-rata sama untuk melihat dan/atau membuka smartphone pada setiap kesempatan, seperti menunggu, mau tidur, bangun tidur, bahkan saat kuliah, dan dalam toilet. Hal ini memberikan kesan bahwa mereka akan membuka/mengecek smartphone hampir setiap saat. Mereka selalu ingin mengetahui hal-hal yang terbaru tentang dunia sekitarnya, dan tidak mau ketinggalan berita, seakan terbentuk dari kedekatan, atau mungkin ketergantungan mereka dengan smartphone yang digunakan. 
Melihat fakta di atas mengenai pola penggunaan teknologi smartphone dan pola komunikasi mahasiswa dengan menggunakan smartphone di kalangan mahasiswa, maka informasi ini dapat dijadikan acuan bagi, misalnya, para pendidik, untuk melibatkan penggunaan smartphone dalam proses belajar mengajar sehingga dapat tercipta atmosfer belajar yang menarik bagi para kaum muda. Dari sini, terbuka pula kemungkinan untuk dilakukan penelitian lanjutan dengan topik yang berkaitan dengan teknologi smartphone dan dunia pendidikan atau proses belajar mengajar.

\section{DAFTAR PUSTAKA}

AC Nielsen. (2010). Mobile Youth Around the World. New York: AC Nielsen.

Hafner, C. A., \& Jones, R. H. (2012). Understanding Digital Literacies. New York: Routledge.

Harian Neraca. (2011, September 28). Diakses January 10, 2013 dari Neraca.co.id: www.neraca.co.id

Kriyantono, R. (2006). Teknis Praktis Riset Komunikasi. Jakarta: Kencana.

Lenhart, A. (2012 , March 19). PewInternet.org. Diakses January 29, 2013 dari http://www.pewInternet.org/Reports/2012/Teens-and-smartphones.aspx

Loogan, R. K. (2010). Understanding New Media: Extending Marshall McLuhan. New York: Peter Lang.

Nasrullah, R. (2012). Komunikasi Antar Budaya di Era Budaya Siber. Jakarta: Kencana.(nd). Dipetik January 29, 2013, dari deccanherald.com: http://www.deccanherald.com/content/125502/smartphones-steal-hearts-youth.html

Oulasvirta, A., Rattenbury, T., Ma, L., \& Raita, A. (2012). Habits Make Smartphone Use More Pervasive. Personal and Ubiquitos Computing , 105-114.

Panji, A. (2012, September 3). Lifestyle. Diakses January 29, 2013 dari kompas.com: http://tekno.kompas.com/read/2012/09/03/0904417/pengguna.blackberry.di.indonesia.terbesar .di.asia.pasifik

Republika Online. (2012, June 21). Diakses January 1, 2013 dari Republika Online: http://www.republika.co.id

Strate, L. (2004). A Media Ecology Review. California: Communication Research Trends, Center for the study of Communication and culture.

Valcanis, T. (2011). An Iphone in Every Hand: Media Ecology, Communication Structures, and The Global Village. ProQuest Research Library, 33-45.

West, R., \& Turner, L. H. (2008). Pengantar Teori Komunikasi, Analisis dan Aplikasi. Jakarta: Salemba Empat.

Zaki, A. (2008). E-Lifestyle, Memanfaatkan Beragam Perangkat Teknologi Digital. Jakarta: Salemba Teknika. 